\title{
SISTEM PENDUKUNG KEPUTUSAN PEMILIHAN SEPEDA MOTOR MENGGUNAKAN METODE MOORA BERBASIS WEB
}

\author{
Anita Febriani ${ }^{1}$, Yuda Irawan ${ }^{2}$, Nurhazimah Rafiah $^{3}$, Refni Wahyuni ${ }^{4}$ \\ 1,2,3,4 Teknik Informatika, STMIK Hang Tuah Pekanbaru \\ E-mail: nitasuheri@gmail.com ${ }^{1}$, yudairawan89@gmail.com² ${ }^{2}$ nurhazimah.rafiah@ gmail.com³ \\ refniabid@gmail.com ${ }^{4}$
}

\begin{abstract}
ABSTRAK
Dalam pemilihan sepeda motor Honda konsumen di CV. Mitra Indo Motor memiliki banyak pilihan motor yang ada berdasarkan tipe, warna dan spesifikasi lainnya yang disediakan oleh pihak dealer. Pemilihan yang dilakukan oleh konsumen tak jarang hanya karena rekomendasi dari pihak marketing atau sales sehingga pemilihannya tidak berdasarkan kebutuhan. Sistem Pendukung Keputusan Berbasis web dapat mempermudah konsumen dalam melakukan pemilihan sepeda motornya, namun sebuah sistem pendukung keputusan membutuhkan sebuah metode yang dapat memecahkan masalah dengan perhitungan matematika yang kompleks. MOORA merupakan metode yang tepat dan hasilnya bisa dijadikan tolak ukur dalam membuat sebuah keputusan berdasarkan perhitungan dan perangkingannya. Pada penelitian ini dilakukan perhitungan manual dengan metode MOORA menggunakan 3 sampel yakni sepeda motor Honda dengan tipe matic dan warna hitam merah menghasilkan Motor Honda dengan Merk Beat CBS, Genio CBS dan Genio CBS ISS. Kemudian dilakukan perhitungan setelah konsumen memasukkan nilai kriteria dari setiap motor dan mengasilkan angka 0,5648 untuk Honda Genio CBS ISS, 0,4226 untuk Honda Genio dan 0,685 untuk Honda Beat CBS. Sehingga dari hasil angka tersebut didapatkan perangkingan dengan Genio CBS ISS sebagai nomor 1 serta pilihan sepeda motor sesuai dengan nilai yang dimasukkan oleh konsumen dan perhitungan metode MOORA. Hasil dari perhitungan manual tersebut telah dicoba dengan memasukkan data tersebut kedalam sistem dan menghasilkan perhitungan yang sama.
\end{abstract}

Kata Kunci : Motor Honda, Sistem Pendukung Keputusan, MOORA.

\begin{abstract}
In the selection of consumer Honda motorbikes at CV. Mitra Indo Motor has many choices of motorbikes based on the type, color and other specifications provided by the dealer. The choices made by consumers are often only because of recommendations from marketing or sales parties so that the selection is not based on need. Web-based Decision Support Systems can make it easier for consumers to choose their motorbikes, but a decision support system requires a method that can solve problems with complex mathematical calculations. MOORA is the right method and the results can be used as benchmarks in making a decision based on calculations and ranking. In this study, manual calculations were carried out using the MOORA method using 3 samples, namely a Honda motorbike with the automatic type and black and red color resulting in a Honda motorbike with the CBS Beat Brand, Genio CBS and Genio CBS ISS. Then the calculation is carried out after the consumer enters the criteria value of each motorbike and generates the number 0.5648 for the Honda Genio CBS ISS, 0.4226 for the Honda Genio and 0.685 for the Honda Beat CBS. So that from the results of this number, the ranking with Genio CBS ISS is number 1 and the choice of motorbike according to the value entered by the consumer and the calculation of the MOORA method. The results of the manual calculations have been tested by entering the data into the system and producing the same calculation.
\end{abstract}

Keywords: Honda Motor, Decision Support System, MOORA. 
IN F O RM A I K A

Jurnal Informatika, Manajemen dan Komputer, Vol. 13 No. 1 , Mei 2021

eISSN : 2580-3042

pISSN : 1979-0694

\section{PENDAHULUAN}

Sepeda motor adalah suatu kendaraan bermotor roda dua yang sangat banyak digunakan dan digemari berbagai kalangan di Pekanbaru. Kegunaanya dalam mempersingkat jarak tempuh sesorang dari satu tempat ke tempat lainnya dengan cepat dan lebih hemat menjadikannya sebagai kebutuhan manusia untuk menunjang aktivitasnya dimasa sekarang ini.

CV. Mitra Indo Motor merupakan suatu perusahaan yang melayani pembelian sepeda motor merek Honda dengan berbagai tipe dan spesifikasi. Tipe sepeda motor Honda yang ditawarkan beragam yakni tipe matic, bebek dan sport. Berdasarkan tiga tipe tersebut, masih banyak varian lainnya dalam sepeda motor Honda yang ditawarkan, yakni dari segi kecepatan, warna, bentuk sepeda motor, kapasitas tangki bensin, besarnya jok, adanya fitur cas hp, adanya fitur idling stop dan banyak lagi spesifikasi sepeda motor Honda yang ditawarkan di CV. Mitra Indo Motor. Berdasarkan tipe dan banyaknya varian yang ditawarkan tentunya membuat konsumen makin bingung ketika melihat langsung banyaknya sepeda motor Honda yang terdapat di CV. Mitra Indo Motor. Namun, ada juga banyak konsumen yang tidak memiliki cukup waktu untuk datang ke dealer kemudian hanya mendapatkan informasi melalui WhatsApp dengan marketing, sehingga informasi yang didapatnya tidak sepenuhnya lengkap dan akhirnya memutusakan memilih sepeda motor berdasarkan rekomendasi marketing, bukan berdasarkan kebutuhannya.

Metode MOORA pertama kali diperkenalkan oleh Brauers dan Zavadskas pada tahun 2006 sebagai multiobjektif sistem yaitu mengoptimalkan dua atau lebih atribut yang saling bertentangan secara bersamaan(Suginan, Emi Suryani, Sapria, Ulandari Lubis, 2018). Pada awalnya metode ini diperkenalkan oleh Brauers pada tahun 2004 sebagai "Multi-Objective Optimization" yang dapat digunakan untuk memecahkan berbagai masalah pengambilan keputusan yang rumit pada lingkungan perusahaan(Al-Hafiz et al., 2017). Metode ini diterapkan untuk memecahkan berbagai jenis masalah dengan perhitungan metematika yang kompleks. Metode MOORA memiliki tingkat fleksibilitas dan kemudahan untuk dipahami dalam memisahkan bagian subjektif dari suatu proses evaluasi ke dalam kriteria bobot keputusan dengan beberapa atribut pengambilan keputusan(Muharsyah et al., 2018). Metode ini memiliki tingkat selektifitas yang baik karena dapat menentukan tujuan dari kriteria yang bertentangan(Safii \& Zulhamsyah, 2018). Dimana kriteria dapat bernilai menguntungkan (benefit) atau yang tidak menguntungkan (cost). Oleh karena itu, peneliti memilih metode ini untuk memudahkan sistem dalam mengambil keputusan terhadap konsumen yang ingin memilih sepeda motor sesuai dengan kebutuhannya, walaupun banyaknya jenis sepeda motor yang ditawarkan oleh CV.Mitra Indo Motor.

Sistem Pendukung Keputusan pertama kali dinyatakan oleh Michael S. Scott Morton pada tahun 1970 dengan istilah "Management Decision System". Pada dasarnya DSS dirancang untuk mendukung seluruh tahap pengambilan keputusan mulai dari mengidentifikasi masalah, memilih data yang relevan, menentukan pendekatan yang digunakan dalam proses pengambilan keputusan, sampai mengevaluasi pemilihan alternatif. Sistem pendukung keputusan ini diperlukan untuk memudahkan kita dalam memilih satu dari banyaknya pilihan yang ada. Seperti halnya dalam sepeda motor yang terdapat di CV.Mitra Indo Motor, sepeda motor tersebut memiliki ragam bentuk yang akhirnya membuat konsumen kebingungan dalam memilihnya sehingga mereka membutuhkan sistem pendukung keputusan yang akan melakukan identifikasi terhadap sepeda motor apa yang menjadi kebutuhan konsumen, kemudian sistem akan memilih data yang paling relevan sesuai data yang 
I N F O R M A I I A

Jurnal Informatika, Manajemen dan Komputer, Vol. 13 No. 1 , Mei 2021

eISSN : 2580-3042

pISSN : 1979-0694

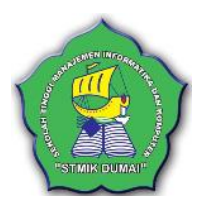

diinputkan oleh konsumen, selanjutnya sistem menentukan pendekatan yang digunakan dalam proses pengambilan keputusan yakni disini kita menggunakan metode MOORA sebagai metode yang akan memudahkan pengambilan keputusan tersebut dengan lebih tepat dan cepat lalu akhirnya sistem dapat mengevaluasi pemilihan tersebut dan menjadikan evaluasi ini sebagai hasil dari proses keputusan atau saran bagi konsumen dalam memilih sepeda motor sesuai keinginan dan kebutuhannya(Mesran et al., 2018).

Oleh karena itu dibutuhkan suatu sistem untuk mempermudah konsumen dalam memilih sepeda motor di CV. Mitra Indo Motor berdasarkan kebutuhannya. Penulis ingin memberikan pemecahan masalah bagi CV. Mitra Indo Motor, dengan merancang suatu sistem informasi untuk memudahkan konsumen dan marketing dalam memilih sepeda motor dan memproses pembelian sepeda motor yang sesuai dengan kebutuhan konsumen. Sistem berbasis web atau online dapat langsung dilihat oleh konsumen diamanapun dan kapanpun serta memudahkan konsumen dalam menerima informasi dan saran yang paling tepat.

\section{METODE PENELITIAN}

Metode penelitian yang digunakan dalam penelitian ini adalah metode waterfall, karena metode ini merupakan metode yang banyak digunakan oleh pengembang software. Inti dari metode ini adalah pengerjaan dari suatu sistem dilakukan secara berurutan atau secara linear.

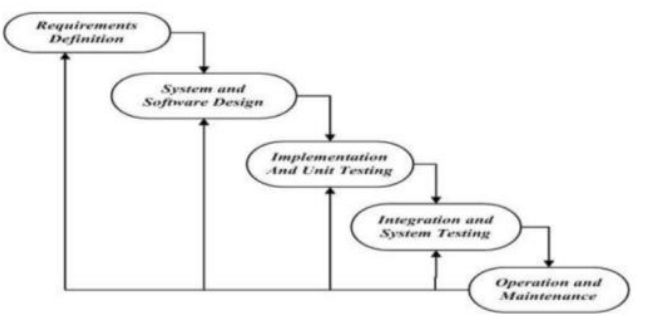

Adapun alur dari tahapan metode tersebut dapat dijabarkan sebagai berikut:

a. Requirements Analysis and Definition

Tahap awal yang dilakukan oleh peneliti adalah merencakan sistem yang dibuat akan menggukan metode Multi Objective Optimization on The Basis of Ratio Analysis (MOORA) untuk menentukan hasil dari pemilihan sepeda motor, kemudian merencanakan bahasa pemrograman PHP dan database MySQL sebagai implementasi sistem.

b. System and Software Design

Setelah melakukan analisis kebutuhan, peneliti melakukan desain sistem yang akan digunakan pada sistem pendukung keputusan pemilihan sepeda motor Honda agar nantinya dapat digunakan dengan lebih mudah oleh konsumen pemilih sepeda motor Honda.

c. Implementation and Unit Testing

Apabila tahap penulisan program yang telah dianalisis dan didesain menggunakan bahasa pemrograman PHP dan database yang digunakan MySql, maka dilakukan pengujian web dengan berbagai teknologi browser yang ada, serta pemeriksaan hasil keputusan menggunakan metode Multi Objective Optimization on The Basis of Ratio Analysis (MOORA).

d. Integration and System Testing

Setelah melakukan implementasi atau menerapkan program, kemudian dilakukan integritas dan percobaan sistem pada konsumen, pada tahan ini juga terdapat evaluasi pada sistem yang telah dibuat sehingga diketahui layak atau dapat digunakan dengan mudah oleh konsumen.

e. Operation and Maintenance

Tahap terakhir yang dilakukan adalah perawatan sistem dengan menyempurnakan kekurangan yang terdapat pada sistem yang telah dibuat baik dari segi koding ataupun metodenya.

Gambar 1. Metode Waterfall 
INFORMA TIK A

Jurnal Informatika, Manajemen dan Komputer, Vol. 13 No. 1 , Mei 2021

eISSN : 2580-3042

pISSN : 1979-0694

\section{Metode Moora}

"Multi-Objective Optimization on the basis of Ratio Analysis (MOORA) adalah multiobjektif sistem mengoptimalkan dua atau lebih atribut yang saling bertentangan secara bersamaan". Metode ini diterapkan untuk memecahkan masalah dengan perhitungan matematika yang kompleks. Moora diperkenalkan oleh Brauers dan Zavadskas pada tahun 2006(Nur et al., 2018). Pada awalnya metode ini diperkenalkan oleh Brauers pada tahun 2004 sebagai "Multi-Objective Optimization " yang dapat digunakan untuk memecahkan berbagai masalah pengambilan keputusan yang rumit pada lingkungan pabrik. Metode MOORA diterapkan untuk memecahkan banyak permasalahan ekonomi, manajerial dan kontruksi pada sebuah perusahaan maupun proyek(Manurung, 2018). Berikut ini adalah algoritma penyelesaian metode MOORA yaitu sebagai berikut:

1. Langkah Pertama : Menginput Nilai Kriteria. Menginput nilai kriteria suatu alternatif dimana nilai tersebut nantinya akan diproses dan hasilnya akan menjadi sebuah keputusan.

2. Langkah Kedua: Merubah nilai kriteria menjadi matriks keputusan. matriks keputusan berfungsi sebagai pengukuran kinerja dari alternatife I th pada atribut $\mathbf{J}$ th, $M$ adalah alternatif dan $\mathrm{n}$ adalah jumlah atribut dan kemudian sistem rasio dikembangkan dimana setiap kinerja dari sebuah alternatif pada sebuah atribut dibandingkan dengan penyebut yang merupakan wakil untuk semua alternatif dan atribut tersebut, berikut adalah perubahan nilai kriteria menjadi sebuah matriks keputusan.

$$
X=\left[\begin{array}{lll}
X_{11} & X_{12} & X_{1 n} \\
X_{21} & X_{22} & X_{2 n} \\
X_{m 1} & X_{m 2} & X_{m n}
\end{array}\right]
$$

Gambar 2. Matriks Keputusan
3. Langkah Ketiga: Normalisasi pada metode Moora. Normalisasi bertujuan untuk menyatukan setiap element matriks sehingga element matriks memiliki nilai yang seragam. Normalisasi pada Moora dapat dihitung menggunakan rumus sebagai berikut:

$$
x_{i j}^{*}=\frac{X_{i . j}}{\sqrt{\left[\sum_{i=1}^{m} x_{i j}^{2}\right]}}
$$

Gambar 3. Normalisasi

4. Langkah Keempat: Mengurangi nilai maximax dan minimax untuk menandakan bahwa sebuah atribut lebih penting itu bisa dikalikan dengan bobot yang sesuai dengan bobot yang sesuai (koefesien signifikan). (Brauers etal.2009 dalam Ozcelik, 2014). Saat atribut bobot dipertimbangkan perhitungan menggunakan persamaan sebagai berikut:

$$
y_{i=} \sum_{j=1}^{g} w_{j} x_{i j-}^{*} \sum_{j=g+1}^{n} w_{j} w_{i j}^{*}
$$

\section{Gambar 4. Persamaan}

5. Langkah Kelima: Menentukan rangking dari hasil perhitungan MOORA.

3. IMPLEMENTASI DAN PEMBAHASAN

1. Tampilan Halaman Utama

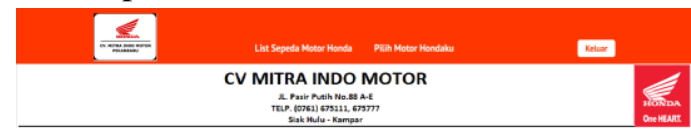

Gambar 5. Halaman Utama 
INFORM T I K A

Jurnal Informatika, Manajemen dan Komputer, Vol. 13 No. 1 , Mei 2021

eISSN : 2580-3042

pISSN : 1979-0694

Desain Tampilan Utama adalah halaman awal yang pertama kali tampil pada saat user mengakses website. Pada tampilan utama ini user dapat melakukan login pada website dengan menekan tombol masuk di pojok kanan atas.

2. Tampilan Halaman Login

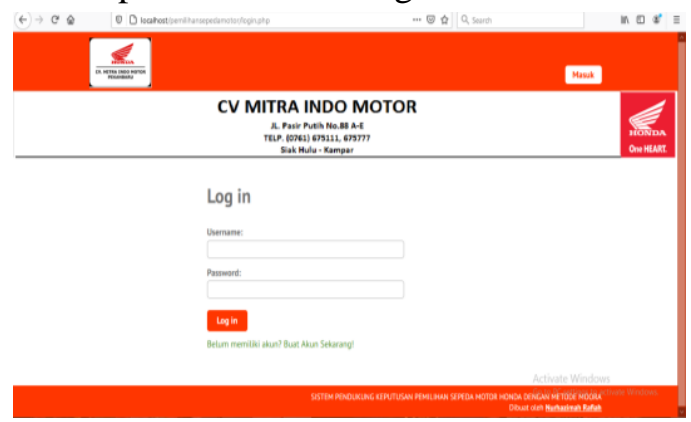

Gambar 6. Halaman Login

Setelah User menekan tombol masuk maka akan muncul tampilan seperti ini, apabila user sudah memiliki akun, maka bisa langsung mengetikkan username dan passwordnya pada menu input dan menekan tombol log in untuk masuk ke menu sesuai username dan password yang diketikkan. Apabila user belum memiliki akun, maka dapat menekan link "Belum memiliki akun? Buat akun sekarang!’.

3. Tampilan Halaman Menu Utama

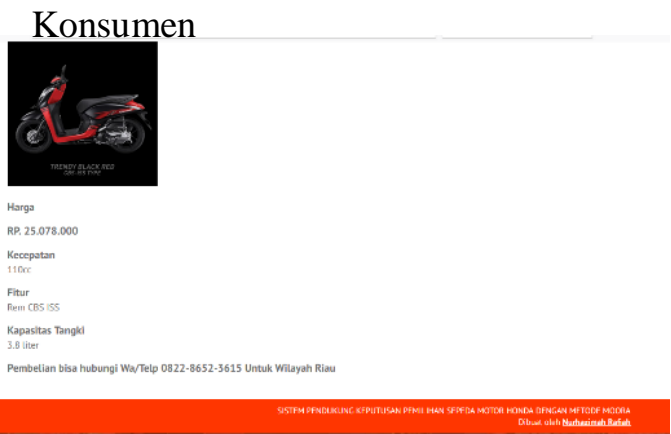

Gambar 7. Halaman Menu Utama

Gambar 10. Halaman Hasil Pilih Motor Konsumen 
IN F ORM A I K A

Jurnal Informatika, Manajemen dan Komputer, Vol. 13 No. 1 , Mei 2021

eISSN : 2580-3042

pISSN : 1979-0694

\section{Tampilan Hasil Pilih Motor Konsumen}

Perankingan Menggunakan Metode MOORA

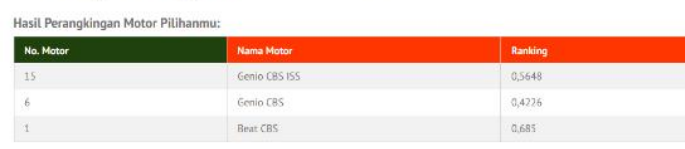

Berdasarkan perangkingan diatas, sepeda motor dengan nilai pilihan tertinggi adalah Genio CBS ISS

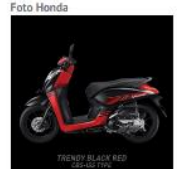

Gambar 11. Halaman Menu Pilih Motor Konsumen

Ini merupakan tampilan menu hasil pilih motor konsumen berdasarkan tipe dan warna yang dipilih konsumen. Pada menu ini konsumen menekan tombol tambah nilai untuk menambahkan nilai kriteria pada motor-motor pilihannya.

7. Tampilan Halaman Menu Isi Nilai Motor Konsumen

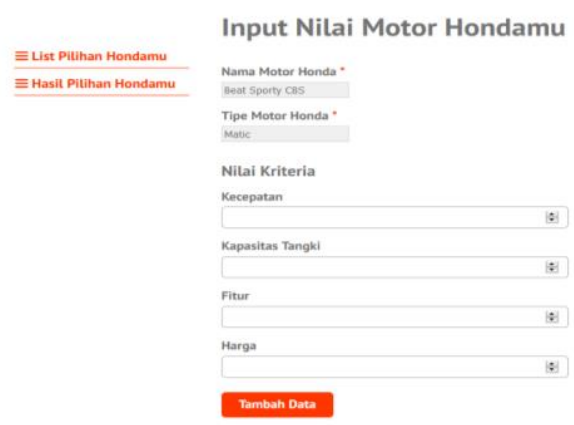

\section{Gambar 12. Halaman Hasil Perangkingan Motor Konsumen}

Ini merupakan tampilan menu isi nilai motor konsumen berdasarkan list motor yang tampil dan konsumen memasukkan nilainilai kriteria untuk mendapatkan hasil perhitungan motornya.
8. Tampilan Halaman Hasil Perangkingan Motor Konsumen

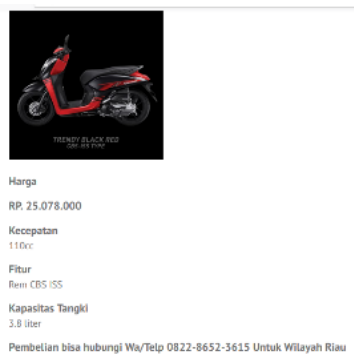

\section{Gambar 13. Halaman Hasil Perangkingan Motor Konsumen}

Ini merupakan tampilan hasil menu perhitungan konsumen yang didapat dengan perhitungan metode MOORA. Hasil yang ditunjukkan program sama dengan nilai manual pengujian yang dilakukan. Dan menunjukkan Motor Genio CBS ISS sebagai pilihan motor konsumen sesuai nilai yang diinputkan konsumen.

\section{Perhitungan Manual Metode MOORA}

Dalam metode (MOORA) terdapat kriteria-kriteria yang dijadikan sebagai bahan perhitungan pada proses penilaian. Hal itu dimaksudkan untuk menentukan sepeda motor yang akan terpilih dari beberapa alternative sepeda motor yang diseleksi.

Langkah pertama yang dilakukan untuk memulai perhitungan dengan metode MOORA adalah menentukan kriteriakriterian penilaian. Berikut adalah data kriteria pemilihan sepeda motor Honda. 
IN F ORM A T I R

Jurnal Informatika, Manajemen dan Komputer, Vol. 13 No. 1 , Mei 2021

eISSN : 2580-3042

pISSN : 1979-0694

\begin{tabular}{|l|l|l|l|l|}
\hline \multirow{2}{*}{$\begin{array}{l}\text { Alternati } \\
\text { f }\end{array}$} & \multicolumn{4}{|l|}{ Kriteria } \\
\cline { 2 - 5 } & C1 & C2 & C3 & C4 \\
\hline \multirow{4}{*}{ A1 } & Rem & $110 \mathrm{c}$ & 4,2 & 17.820 .00 \\
& Cbs & c & L & 0 \\
\hline \multirow{2}{*}{ A2 } & Rem & $125 c$ & 4,5 & 25.078 .00 \\
\hline \multirow{4}{*}{ A3 } & Cbs & c & L & 0 \\
\hline & Rem & & & \\
Cbs & $150 c$ & 7,2 & 25.078 .00 \\
\hline
\end{tabular}

Tabel 3. Data Nilai Kriteria Fitur

\begin{tabular}{|l|l|}
\hline Fitur & Nilai \\
\hline Rem CBS & 1 \\
\hline Rem CBS Iss & 2 \\
\hline Rem ABS & 3 \\
\hline
\end{tabular}

Tabel diatas memberikan nilai pada setiap fitur yang ada yakni rem CBS dengan nilai 1, CBS ISS dengan nilai 2 dan ABS dengan nilai 3 .

\section{Tabel 4. Data Nilai Kriteria Kecepatan}

Tabel 1. Kriteria Sepeda Motor Honda

\begin{tabular}{|l|l|l|l|}
\hline Kriteria & Keterangan & Bobot & Jenis \\
\hline C1 & Fitur & $25 \%$ & Benefit \\
\hline C2 & Kecepatan & $25 \%$ & Benefit \\
\hline C3 & $\begin{array}{l}\text { Kapasitas } \\
\text { Tangki }\end{array}$ & $35 \%$ & Benefit \\
\hline C4 & Harga & $15 \%$ & Cost \\
\hline
\end{tabular}

Tabel ini merupakan kriteria sepeda motor yang telah ditentukan bobot dan jenis benefitnya berdasarkan pemikiran penulis. Langkah selanjutnya menentukan kriteria penilaian untuk setiap alternatif. Berikut ini adalah data Alternatif pemilihan sepeda motor Honda :

Tabel 2. Alternatif Pemilihan Sepeda Motor

\begin{tabular}{|l|l|}
\hline Alternatif & Merk \\
\hline A1 & Beat CBS \\
\hline A2 & Genio CBS \\
\hline A3 & Genio CBS ISS \\
\hline
\end{tabular}

Tabel diatas adalah alternatif dalam pemilihan sepeda motor dengan tipe dan jenis warna yang sama.

Kemudian Menentukan data Rating Kecocokan alternatif dan kriteria pada sepeda motor Honda. Tabel diatas merupakan data alternatif dan nilai dari kriteria yang akan diolah menjadi nilai pada setiap kriterianya seperti tabel berikut ini:

\begin{tabular}{|l|l|}
\hline Kecepatan & Nilai \\
\hline $110 \mathrm{cc}$ & 1 \\
\hline $125 \mathrm{cc}$ & 2 \\
\hline $150 \mathrm{cc}$ & 3 \\
\hline
\end{tabular}

Tabel diatas memberikan nilai pada setiap kecepatan yang ada yakni kecepatan $110 \mathrm{cc}$ dengan nilai $1,125 \mathrm{cc}$ dengan nilai 2 dan $150 \mathrm{cc}$ dengan nilai 3 .

Tabel 5. Data Nilai Kriteria Kapasitas Tangki

\begin{tabular}{|l|l|}
\hline Kapasitas Tangki & Nilai \\
\hline $3,8 \mathrm{~L}$ & 1 \\
\hline $4,5 \mathrm{~L}$ & 2 \\
\hline $7,2 \mathrm{~L}$ & 3 \\
\hline
\end{tabular}

Selanjutnya didapatkan nilai dari setiap kriteria alternatif

Tabel 6. Tabel Nilai Kriteria setiap alternatif

\begin{tabular}{|l|l|l|l|l|}
\hline \multirow{2}{*}{ Alternatif } & \multicolumn{4}{|l|}{ Kriteria } \\
\cline { 2 - 5 } & C1 & C2 & C3 & C4 \\
\hline A1 & 1 & 1 & 1 & 1 \\
\hline A2 & 1 & 2 & 2 & 2 \\
\hline A3 & 2 & 3 & 3 & 3 \\
\hline
\end{tabular}


IN F O R M A I I A

Jurnal Informatika, Manajemen dan Komputer, Vol. 13 No. 1 , Mei 2021

eISSN : 2580-3042

pISSN : 1979-0694

Tabel diatas memberikan nilai kriteria setiap alternatif, A1, A2 dan A3 merupakan Alternatif yang sudah kita buat diatas, lalu C1, C2, C3 dan C4 merupakan kriteria serta nilai yang sudah kita kelompokkan diatas.

Kemudian Membuat matriks keputusan xij berdasarkan tabel diatas<smiles>C1CCCCCC1</smiles>

Gambar diatas merupakan matriks yang saya buat berdasarkan tabel nilai kriteria setiap alternatif sehingga menjadi matriks dengan ordo 3 baris 4 kolom.

Lalu Kuadratkan $\mathrm{x}$ atau nilai dari setiap alternatif $\mathrm{j}$ pada atribut $\mathrm{i}$

$\left(\begin{array}{llll}1 & 1 & 1 & 1 \\ 1 & 4 & 4 & 4 \\ 2 & 9 & 9 & 9\end{array}\right)$

\section{Gambar 14. Matriks Kuadrat Keputusan}

Gambar diatas merupakan matriks yang dihasilkan dari mengkuadrat seluruh angka di matriks keputusan yang saya buat diatas.

Kemudian menentukan matriks yang dinormalisasikan dengan menggunakan persamaan 1. Adapun langkah-langkah pemilihan sepeda motor Honda dengan menggunakan metode (MOORA) adalah sebagai berikut:

\section{Tabel 7. Tabel Normalisasi Matriks}

\begin{tabular}{|l|r|r|r|r|}
\hline \multirow{2}{*}{ Alternatif } & \multicolumn{5}{|c|}{ Kriteria } \\
\cline { 2 - 6 } & C1 & C2 & C3 & C4 \\
\hline A1 & 1 & 1 & 1 & 1 \\
\hline A2 & 1 & 4 & 4 & 4 \\
\hline A 3 & 4 & 9 & 9 & 9 \\
\hline$\sqrt{ } \mathrm{x}^{2}$ & 6 & 14 & 14 & 14 \\
\hline$\sqrt{ } \mathrm{x}^{2}$ & 2,449489743 & 3,7416574 & 3,741657387 & 3,741657387 \\
\hline
\end{tabular}

Lakukan perhitungan Hitung dengan rumus

$$
X_{i j}^{*}=\frac{x_{i j}}{\sqrt{\left[\sum_{\mathrm{j}=1}^{\mathrm{m}} x_{\mathrm{ij}}^{2}\right]}}
$$

Gambar 8. Rumus Normalisasi
$\mathrm{X} 11 *=(\mathrm{X} 11 / \sqrt{ } \Sigma \mathrm{x} 2)=0,4082$

$\mathrm{X} 12 *=(\mathrm{X} 12 / \sqrt{ } \Sigma \mathrm{X} 2)=0,4082$

$\mathrm{X} 13 *=(\mathrm{X} 13 / \sqrt{ } \Sigma \mathrm{X} 2)=0,8164$

$\mathrm{X} 21 *=(\mathrm{X} 21 / \sqrt{ } \Sigma \mathrm{X} 2)=0,2672$

$\mathrm{X} 22 *=(\mathrm{X} 22 / \sqrt{ } \Sigma \mathrm{x} 2)=0,5345$

$\mathrm{X} 23 *=(\mathrm{X} 23 / \sqrt{ } \Sigma \mathrm{x} 2)=0,8017$

$\mathrm{X} 31^{*}=(\mathrm{X} 31 / \sqrt{ } \Sigma \mathrm{x} 2)=0,2672$

$\mathrm{X} 32 *=(\mathrm{X} 32 / \sqrt{ } \Sigma \mathrm{x} 2)=0,5345$

$\mathrm{X} 33 *=(\mathrm{X} 33 / \sqrt{ } \Sigma \mathrm{x} 2)=0,8017$

$\mathrm{X} 41^{*}=(\mathrm{X} 41 / \sqrt{ } \Sigma \mathrm{x} 2)=0,2672$

$\mathrm{X} 42 *=(\mathrm{X} 42 / \sqrt{ } \Sigma \times 2)=0,5345$

$\mathrm{X} 43 *=(X 43 / \sqrt{ } \Sigma \times 2)=0,8017$

Hasil perhitungan dari normalisasi matrix $\mathrm{X} * \mathrm{ij}$ adalah

$$
\left(\begin{array}{llll}
0,4082 & 0,2672 & 0,2672 & 0,2672 \\
0,4082 & 0,5345 & 0,5345 & 0,5345 \\
0,8164 & 0,8017 & 0,8017 & 0,8017
\end{array}\right)
$$

\section{Gambar 15. Matriks Normalisasi}

Gambar diatas merupakan matriks yang dihasilkan dari perhitungan matriks keputuasan dengan jumlah kuadrat seluruk angka alternatif setiap kriteria. Hasil tersebut disusun berdasarkan hasil setiap baris dan kolomnya sehingga menjadi sebuah matrikas normalisasi.

Kemudian Menentukan matriks Normalisasi terbobot. Setiap angka di kolom dan baris pada matriks normalisasi dikalikan dengan bobot setiap kriteria yang sudah kita sebutkan dalam tabel bobot diatas.

$$
\begin{aligned}
\mathrm{Wj} 11=\mathrm{X} 11(0,4082) & * 0,25=0,1021 \\
\mathrm{Wj} 12=\mathrm{X} 12(0,4082) & * 0,25=0,1021 \\
\mathrm{Wj} 13=\mathrm{X} 13(0,8614) & * 0,25=0,2041 \\
\mathrm{Wj} 21=\mathrm{X} 21(0,2762) & * 0,25=0,0668 \\
\mathrm{Wj} 22=\mathrm{X} 22(0,5345) & * 0,25=0,1336
\end{aligned}
$$


I N F O R M A T I K A

Jurnal Informatika, Manajemen dan Komputer, Vol. 13 No. 1 , Mei 2021

eISSN : 2580-3042

pISSN : 1979-0694

Wj23 $=$ X23 $(0,8017) * 0,25=0,2004$
Wj31 $=$ X31 $(0,2672) * 0,35=0,9352$
Wj32 $=$ X32 $(0,5345) * 0,35=0,1871$
Wj33 $=$ X33 $(0,8017) * 0,35=0,2805$
Wj41 $=$ X41 $(0,2672) * 0,15=0,0401$
Wj42 $=$ X42 $(0,5345) * 0,15=0,0801$
Wj43 $=$ X43 $(0,8017) * 0,15=0,1202$

Kemudian hasil perhitungan diatas akan menghasilkan sebuat matriks yang dibuat sesuai dengan kolom dan barisnya seperti gambar di bawah ini:

$\left(\begin{array}{llll}0,1021 & 0,0935 & 0,0668 & 0,0401 \\ 0,1021 & 0,1871 & 0,1334 & 0,0801 \\ 0,2041 & 0,2805 & 0,2004 & 0,1202\end{array}\right)$

\section{Gambar 16. Matriks bobot}

Kemudian lakukan pengurangan maximax dan minimax.

Maximax ditentukan berdasarkan nilai yang jenis bobotnya benefit dan minimax dari nilai yang jenis bobotnya cost. Pada matriks diatas 3 kolom dan 3 barisnya merupakan kriteria dengan jenis bobot benefit dan pada kolom 4 seluruh barisnya merupakan kriteria yang jenis bobotnya cost sehingga merupakan nilai minimax.

Kemudian dapat dilakukan perhitungan seperti ini :

\section{Tabel 10 Tabel Yi}

\begin{tabular}{|l|r|r|r|}
\hline Alternatif & $\max (\mathrm{X} 1+\mathrm{X} 2+\mathrm{X} 3)$ & $\min (\mathrm{X} 4)$ & $\mathrm{Y} 1(\max -\min )$ \\
\hline $\mathrm{A} 1$ & 0,2624 & 0,0401 & 0,2223 \\
\hline $\mathrm{A} 2$ & 0,4226 & 0,0801 & 0,3425 \\
\hline $\mathrm{A} 3$ & 0,685 & 0,1202 & 0,5648 \\
\hline
\end{tabular}

Tabel diatas merupakan tabel yang menerangkan hasil dari perhitungan angka maximax dan minimax. Angka pada 3 kolom setiap barisnya dijumlahkan lalu dikurangi dengan angka pada setiap baris kolom 4 .

Kemudian berdasakan perhitungan $\operatorname{minimax}$ dan maximax diatas maka didapatlah hasil perangkingan seperti tabel dibawah ini:
Tabel 11. Tabel Perangkingan

\begin{tabular}{|l|l|l|}
\hline Alternatif & Hasil & Rangking \\
\hline A3 & 0,5648 & 1 \\
\hline A2 & 0,4226 & 2 \\
\hline A1 & 0,685 & 3 \\
\hline
\end{tabular}

Dari hasil perhitungan tabel alternatif A1 Genio CBS ISS) merupakan nilai yang tertinggi dibandingkan dengan nilai alternatif A3 (Beat CBS) maka yang dipilih konsumen untuk merk sepeda motor Honda yang sesuai kebutuhannya adalah Genio CBS ISS dengan nilai tertinggi.

\section{KESIMPULAN}

Hasil dari perancangan yang telah dilakukan dapat membuat Sistem Pemilihan Sepeda Motor berbasis web menggunakan metode MOORA yang mempermudah konsumen dan sales dalam pemilihan sepeda motor bagi konsumen sesuai dengan kebutuhannya. Dari hasil implementasi pada Sistem Pemilihan Sepeda Motor berbasis web menggunakan metode MOORA dapat dijadikan tolak ukur dalam pemilihan sepeda motor dikarenakan sudah dilakukan perhitungan dengan metode. Hasil dari perhitungan manual dan sistem dengan metode MOORA dengan 3 sampel yang digunakan yakni sepeda motor Honda dengan tipe matic dan warna hitam merah menghasilkan Motor Honda dengan Merk Beat CBS, Genio CBS dan Genio CBS ISS. Kemudian dilakukan perhitungan setelah konsumen memasukkan nilai kriteria dari setiap motor dan mengasilkan angka 0,5648 untuk Honda Genio CBS ISS, 0,4226 untuk Honda Genio dan 0,685 untuk Honda Beat CBS. Sehingga dari hasil angka ini didapatkan perangkingan dengan Genio CBS ISS sebagai nomor 1 serta pilihan sepeda motor sesuai dengan nilai yang dimasukkan oleh konsumen dan perhitungan metode MOORA 
INFORM T I K A

Jurnal Informatika, Manajemen dan Komputer, Vol. 13 No. 1 , Mei 2021

eISSN : 2580-3042

pISSN : 1979-0694

\section{REFERENSI}

Al-Hafiz, N. W., Mesran, \& Suginam. (2017). Sistem Pendukung Keputusan Penentukan Kredit Pemilikan Rumah Menerapkan Multi-Objective Optimization on the Basis of Ratio Analysis ( Moora ). KOMIK (Konferensi Nasional Teknologi Informasi Dan Komputer), I(1), 306$309 . \quad$ http://www.stmikbudidarma.ac.id/ejurnal/index.php/kom $\mathrm{ik} /$ article/viewFile/513/455

Manurung, S. (2018). Sistem Pendukung Keputusan Pemilihan Guru Dan Pegawai Terbaik Menggunakan Metode Moora. Simetris: Jurnal Teknik Mesin, Elektro Dan Ilmu Komputer, 9(1), 701-706. https://doi.org/10.24176/simet.v9i1.196 7

Mesran, M., Pardede, S. D. A., Harahap, A., \& Siahaan, A. P. U. (2018). Sistem Pendukung Keputusan Pemilihan Peserta Jaminan Kesehatan Masyarakat (Jamkesmas) Menerapkan Metode MOORA. Jurnal Media Informatika Budidarma, 2(2), 16-22. https://doi.org/10.30865/mib.v2i2.595

Muharsyah, A., Hayati, S. R., Setiawan, M. I., Nurdiyanto, H., \& Yuhandri. (2018). Sistem Pendukung Keputusan Multi Obective Optimization On the Basis Of Ratio Analysis (MOORA). JURIKOM (Jurnal Riset Komputer), 5(2), 19-23. http://ejurnal.stmikbudidarma.ac.id/index.php/jurikom

Nur, K. N. A., Andani, S. R., \& Poningsih, P. (2018). Sistem Pendukung Keputusan Pemilihan Operator Seluler Menggunakan Metode Multi-Objective Optimization on the Basis of Ratio Analysis (Moora). KOMIK (Konferensi Nasional Teknologi Informasi Dan Komputer), 2(1), 305-310. https://doi.org/10.30865/komik.v2i1.94 2

Safii, M., \& Zulhamsyah, A. (2018). Sistem
Pendukung Keputusan Pemilihan Mekanik Sepeda Motor Yamaha Alfascorfii Dengan Metode Multi Objective Optimization On The Basis Of Ratio Analysis (MOORA). J-SAKTI (Jurnal Sains Komputer Dan Informatika), 2(2), 162. https://doi.org/10.30645/j-sakti.v2i2.79 Suginan, Emi Suryani, Sapria, Ulandari Lubis, M. (2018). Sistem Pendukung Keputusan Penerima Bantuan Siswa Miskin Menerapkan Metode WASPAS dan MOORA. Seminar Nasional Sains \& Teknologi Informasi, 719-727.

Mustika, Budy, Et Al. Implementasi Text Mining Pada Twitter Dengan Algoritma K-Means Clustering Sebagai Dasar Kebijakan Marketing Biro Perjalanan Wisata. Jurnal Ilmu Komputer, 2020, 9.2: 134-147.

Ordila, Rian, Et Al. Penerapan Data Mining Untuk Pengelompokan Data Rekam Medis Pasien Berdasarkan Jenis Penyakit Dengan Algoritma Clustering (Studi Kasus: Poli Klinik Pt. Inecda). Jurnal Ilmu Komputer, 2020, 9.2: 148-153. 